\title{
Electrochemical Determination of Hydrogen Peroxide by a Nonenzymatic Catalytically Enhanced Silver-Iron (III) Oxide/Polyoxometalate/ Reduced Graphene Oxide Modified Glassy Carbon Electrode
}

\section{Natasha Ross \& Noniko Civilized Nqakala}

To cite this article: Natasha Ross \& Noniko Civilized Nqakala (2020) Electrochemical Determination of Hydrogen Peroxide by a Nonenzymatic Catalytically Enhanced Silver-Iron (III) Oxide/Polyoxometalate/Reduced Graphene Oxide Modified Glassy Carbon Electrode, Analytical Letters, 53:15, 2445-2464, DOI: 10.1080/00032719.2020.1745223

To link to this article: https://doi.org/10.1080/00032719.2020.1745223

View supplementary material $₫$

Published online: 20 Apr 2020.

Submit your article to this journal $\longleftarrow$

Џll Article views: 88

Q

View related articles $\sqsubset$

View Crossmark data 


\title{
Electrochemical Determination of Hydrogen Peroxide by a Nonenzymatic Catalytically Enhanced Silver-Iron (III) Oxide/ Polyoxometalate/Reduced Graphene Oxide Modified Glassy Carbon Electrode
}

\author{
Natasha Ross and Noniko Civilized Nqakala \\ SensorLab, Department of Chemistry, University of Western Cape, Bellville, Cape Town, South Africa
}

\begin{abstract}
The synergism of phosphomolybdic acid hydrate (POM) decorated with silver-iron (III) oxide $\left(\mathrm{Ag}-\mathrm{Fe}_{2} \mathrm{O}_{3}\right)$ nanoparticles and anchored on reduced graphene oxide ( $\mathrm{RGO}$ ) have been demonstrated to be effective as a nonenzymatic $\mathrm{H}_{2} \mathrm{O}_{2}$ sensor platform. The assembly of the sensor components and their interactions were probed morphologically, spectroscopically and electrochemically. The $\mathrm{Ag}-\mathrm{Fe}_{2} \mathrm{O}_{3} /$ POM/RGO nanocomposite sensor provided an enhanced electroactive surface area, electrical conductivity and sensitivity for hydrogen peroxide compared to an unmodified glassy carbon electrode (GCE) at $-0.55 \mathrm{~V}$ versus a saturated calomel electrode. The developed sensor amperometric response was linear across the concentration range from $0.3 \mathrm{mM}$ to $3.3 \mathrm{mM}\left(\mathrm{R}^{2}=0.992\right)$ with a detection limit and sensitivity of $0.2 \mu \mathrm{M}$ and $271 \mu \mathrm{A} \cdot \mathrm{mM}^{-1} \cdot \mathrm{cm}^{-2}$ respectively. Concomitantly, a short response time of $\mathrm{T} 90<5 \mathrm{sec}$ at a signal-tonoise ratio of 4 was achieved. The sensor was shown to determine hydrogen in the presence of interfering species, and exhibited high selectivity with relative standard deviation values less than $4.2 \%$. The results indicate that the use of RGO to anchor and photochemically reduce POM also improved the reduction properties due to the irregular size distribution and catalytic activity of $\mathrm{Ag}-\mathrm{Fe}_{2} \mathrm{O}_{3}$ stimulated by its adhesion to the distinctive POM/RGO matrix.
\end{abstract}

\section{ARTICLE HISTORY}

Received 17 December 2019

Accepted 17 March 2020

\section{KEYWORDS}

Amperometry; electrochemistry; electron-transfer kinetics; nanocomposite; polyoxometalate (POM; reduced graphene oxide); transition metal nanoparticles

\section{Introduction}

Hydrogen peroxide $\left(\mathrm{H}_{2} \mathrm{O}_{2}\right)$ is a mediator used in food, pharmaceutical, diagnostic, environmental protection and industrial applications (Farah et al. 2012). High levels of hydrogen peroxide have shown to have detrimental effects on biological as well as environment processes. It is for this reason that the accurate and sensitive detection of $\mathrm{H}_{2} \mathrm{O}_{2}$ levels has become a fundamental task in different environments and for a vast range of applications (Deng and Zuo 1999; Yusoff et al. 2017; Al-Hardan et al. 2018).

Several techniques including chromatography, colorimetry, chemiluminescence, titrimetry, spectrophotometry, fluorimetry and electrochemistry (Keston and Brandt 1965; Bader, Sturzenegger, and Hoigné 1988; Uchida et al. 2004; Tarvin et al. 2010; Liu

CONTACT Natasha Ross nross@uwc.ac.za@ SensorLab, Department of Chemistry, University of Western Cape, Private Bag X17, Bellville, Cape Town 7535, South Africa. 
et al. 2011; Hsu et al. 2015) have been developed to detect and measure hydrogen peroxide (L. Wang et al. 2013; Ma et al. 2016). However, electrochemical methods have become more attractive due to the low cost, simple experimental set up and sensitive and fast detection rates with reported sensitivities as high as $0.01\left(\mu \mathrm{A} \cdot \mathrm{mM}^{-1} \mathrm{~cm}^{-2}\right)$ and low detection limits ranging from 0.01 to $57000 \mu \mathrm{M}$ (Liu et al. 2012; Liu, Weng, et al. 2017; Kumar, Chandana, et al.). To enhance the sensitivity and efficiency of electrochemical sensors, the electrode may be fabricated using carbon nanomaterials (Ma et al. 2019) nanostructured metal oxides, conducting polymers, and metal and metal alloy nanomaterials composites (Teymourian, Salimi, and Khezrian 2013).

In this work, reduced graphene oxide, was employed as a specific material for electrochemical interrogation due to its ability to provide a large specific surface area for the attachment and prevention of colloidal aggregation of large quantities of nanoparticles, metals and biomolecules (Sadakane and Steckhan 1998; Miao et al. 2016). Polyoxometalates (POMs) are stable and highly negatively charged units with fascinating electronic and chemical versatility (Pan, Tang, and Chen 2013). POMs have strong attraction toward carbonaceous nanomaterials such as graphene because of the possibility of electron transfer and electrostatic interactions.

Therefore, the immobilization of POMs onto as stable platform such as RGO may increase the number of active sites which may enhance the performance in terms of sensor applications (Xu et al. 2019). Concomitantly, the application of magnetic nanoparticles, particularly iron oxide $\left(\mathrm{Fe}_{2} \mathrm{O}_{3}\right)$ have been extensively used in electrochemical sensors, catalysis and biological applications. Composites of iron oxide nanoparticles with other metals or transition metals oxide have attracted much attention due to their ability to catalyze and enhanced electrochemical reactions.

Among these nanocomposites are silver/iron oxide nanocomposites $\left(\mathrm{Ag}-\mathrm{Fe}_{2} \mathrm{O}_{3}\right)$ used in catalysis for water oxidation and for the oxidation of carbon monoxide (Narasimharao, AlShehri, and Al-Thabaiti 2015). However, to our knowledge, the functionalization of POMs with the $\mathrm{Ag}-\mathrm{Fe}_{2} \mathrm{O}_{3}$ for use as electrochemical environmental sensors has received limited attention. The interest in integrating Ag into the iron oxide composite is to explore its capacity to improve the high electrical conductivity, surface area and biocompatibility (Evanoff and Chumanov 2005). However, Ag nanoparticles aggregate, hence limiting their use.

Therefore, many reports have shown that host materials can prevent the nanoparticles from aggregation (Xu et al. 2011; Bai et al. 2014; Bai et al. 2016). Accordingly, this work reports the absorption of $\mathrm{Fe}_{2} \mathrm{O}_{3}-\mathrm{Ag}$ nanoparticle on phosphomolybdic acid hydrate (POM); stabilized and activated by graphene oxide to form a $\mathrm{Ag}-\mathrm{Fe}_{2} \mathrm{O}_{3}-\mathrm{POM} /$ RGO functionalized nanoelectrode to promote the direct electron transfer between $\mathrm{H}_{2} \mathrm{O}_{2}$ and the electrolyte with enhanced detection efficiency. This study presents the results for the development of a cost effective, highly sensitive and selective hydrogen peroxide sensor without the application of an enzyme.

\section{Experimental}

\section{Chemicals and reagents}

The chemicals used in this study were: graphite powder $(\mathrm{C})$ extra pure purchased from Merck Pty, sulfuric acid $\left(\mathrm{H}_{2} \mathrm{SO}_{4}, 95.0-98.0 \%\right)$, potassium permanganate $\left(\mathrm{KMnO}_{4}\right.$, $\leq$ 
99.9\%), hydrogen peroxide $\left(\mathrm{H}_{2} \mathrm{O}_{2}, 30 \%\right)$, silver nitrate $\left(\mathrm{AgNO}_{3}, 99.0 \%\right)$, polyvinyl alcohol $\left(\left(\mathrm{C}_{2} \mathrm{H}_{4} \mathrm{O}\right) \mathrm{x}\right)$, isopropyl $\left(\mathrm{C}_{3} \mathrm{H}_{8} \mathrm{O}\right)$, phosphomolybdic acid hydrate $\left(\mathrm{H}_{3} \mathrm{Mo}_{12} \mathrm{O}_{40} \mathrm{P} \cdot \mathrm{xH}_{2} \mathrm{O}\right)$ and ethylene glycol $\left(\mathrm{C}_{2} \mathrm{H}_{6} \mathrm{O}_{2}, 99.8 \%\right)$. All were purchased from Sigma Aldrich.

Sodium borohydride $\left(\mathrm{NaBH}_{4}, \leq 99.9 \%\right)$ and urea $\left(\mathrm{CH}_{4} \mathrm{~N}_{2} \mathrm{O}, 95 \%\right)$ were obtained from Fluka Analytical and ethanol $\left(\mathrm{C}_{2} \mathrm{H}_{5} \mathrm{OH}, 99.9 \%\right)$ and ferric chloride $\left(\mathrm{FeCl}_{3} \cdot 6 \mathrm{H}_{2} \mathrm{O}\right.$, 99\%) were from Kimix.

Graphene oxide was prepared using the modified Hummers method with minor adjustments (Loryuenyong et al. 2013). Typically, $50 \mathrm{~mL}$ of concentrated $\mathrm{H}_{2} \mathrm{SO}_{4}$ were added to $2 \mathrm{~g}$ of graphite powder with stirring at standard temperature and pressure. After cooling to $0{ }^{\circ} \mathrm{C}, 7 \mathrm{~g}$ of $\mathrm{KMnO}_{4}$ were slowly added followed by the addition of $120 \mathrm{~mL}$ of $\mathrm{H}_{2} \mathrm{O}$ and $20 \mathrm{~mL} \mathrm{H}_{2} \mathrm{O}_{2}$ (30\% wt.) until gas evolution stopped.

The resulting yellowish-brown suspension was extensively washed with ethanol and water and centrifuged to remove the residual exfoliated graphite. In a typical reduction process, $1 \mathrm{~g}$ of GO was dispersed in $200 \mathrm{~mL}$ distilled water and stirred by ultrasonic treatment for $3 \mathrm{hrs}$ followed by addition of $2 \mathrm{~g}$ of $\mathrm{NaBH}_{4}$. The solution was then heated from 80 to $100{ }^{\circ} \mathrm{C}$ under a water-cooled condenser for $12 \mathrm{~h}$.

The obtained RGO was dried in a vacuum oven for $24 \mathrm{~h}$. The POM was deposited following a method reported earlier with slight modifications (Kim and Shanmugam 2013). In a classic process, $1 \mathrm{~g}$ of RGO was transferred to $800 \mathrm{~mL}$ water containing $8 \mathrm{~mL}$ of ethylene glycol with sonication for $30 \mathrm{~min}$. To this solution, $10 \mathrm{~g}$ of POM were added followed by sonication for 10 -min and irradiation under $300 \mathrm{~W}$ ultraviolet light for $2 \mathrm{~h}$ to facilitate the complete photoreduction.

Subsequently, the mixture was stirred in the dark at room temperature for $48 \mathrm{~h}$. A yellowish-brown to blue-black color change was observed which indicated the formation of the final POM/RGO product.

\section{Construction of $\mathrm{Ag}-\mathrm{Fe}_{2} \mathrm{O}_{3} / \mathrm{POM} / \mathrm{RGO}$ nanocomposite sensor}

For the synthesis of the $\mathrm{Ag}-\mathrm{Fe}_{2} \mathrm{O}_{3} / \mathrm{POM} / \mathrm{RGO}$ nanocomposite, $20 \mathrm{~mL}$ aqueous solution of $1.8 \mathrm{mg} \mathrm{mL}^{-1} \mathrm{POM} / \mathrm{RGO}$ were mixed with $0.084 \mathrm{~g}$ of $\mathrm{AgNO}_{3}(500 \mu \mathrm{M})$ and $0.80 \mathrm{~g}$ of $\mathrm{Fe}\left(\mathrm{NO}_{3}\right)_{3} \cdot 9 \mathrm{H}_{2} \mathrm{O}(2000 \mu \mathrm{M})$ with stirring for $15 \mathrm{~min}$. Thereafter, $1.08 \mathrm{~g}$ of urea $\left(\mathrm{CH}_{4} \mathrm{~N}_{2} \mathrm{O}\right)(0.018 \mathrm{M})$ and $2 \mathrm{~g}$ of polyethylene glycol $(\mathrm{PEG})(500 \mu \mathrm{M})$ were added followed by sonication for $30 \mathrm{~min}$ at $25^{\circ} \mathrm{C}$. The resulting solution was mixed with $80 \mathrm{~mL}$ distilled water and placed in a stainless-steel autoclave that was heated to $180^{\circ} \mathrm{C}$ for $8 \mathrm{~h}$.

The black colored product was allowed to cool at room temperature followed by successive washing with water and ethanol. Finally, the product was dried at $60^{\circ} \mathrm{C}$ in a vacuum oven for $8 \mathrm{~h}$ and was labeled to be the $\mathrm{Ag}-\mathrm{Fe}_{2} \mathrm{O}_{3} / \mathrm{POM} / \mathrm{RGO}$ nanocomposite. For comparison, untreated $\mathrm{Ag}-\mathrm{Fe}_{2} \mathrm{O}_{3}$ nanocomposites were prepared under similar conditions without the addition of POM/RGO.

\section{Characterizations and apparatus}

The surface morphologies of the prepared materials were probed by high resolution transmission electron microscopy (HR TEM Tecnai F20) and scanning electron 

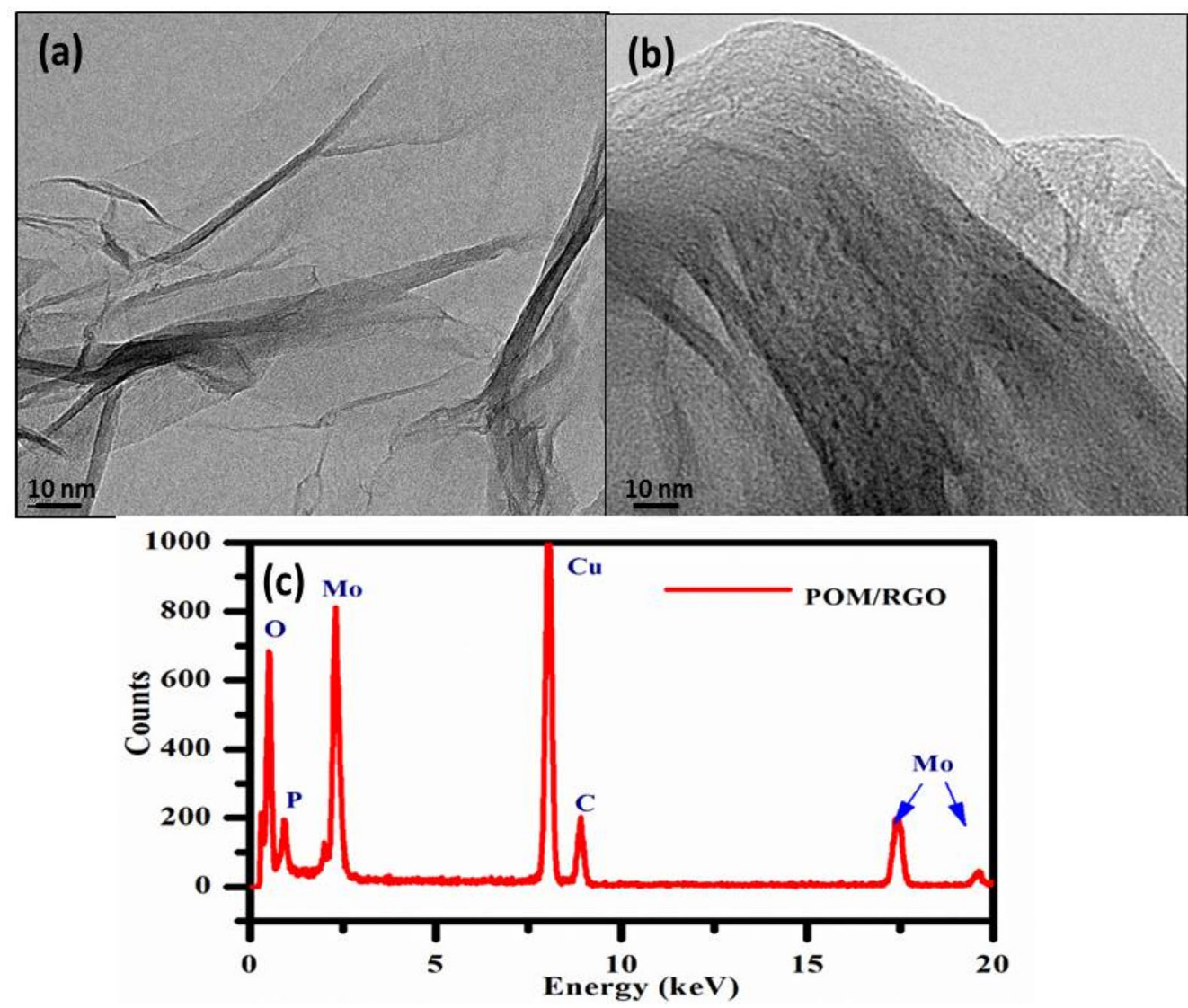

Figure 1. (a) TEM images of RGO, (b) POM/RGO and (c) the corresponding EDX analysis of the region shown in (b).

microscopy (SEM; Auriga HR Zeiss Oxford). The images were collected at $5 \mathrm{kV}$ with a working distance of $6 \mathrm{~mm}$.

Energy dispersive X-ray spectroscopy (EDXS) was used to verify the weight percentages of the synthesized materials.

Fourier transform infrared spectroscopy (FTIR) was used to characterize the vibrational spectra of the samples.

The structures were further interrogated by X-ray diffraction (XRD).

Electrochemical studies were performed on a PalmSens3 potentiostat/galvanostat electrochemical workstation (PalmSens BV, Houten, Netherlands) monitored by the PSTrace software. The measurements were performed at a potential window of $-0.2 \mathrm{~V}$ to $0.8 \mathrm{~V}$ in the presence and absence of $1 \mathrm{mM} \mathrm{H}_{2} \mathrm{O}_{2}$ in an electrolyte medium of $0.5 \mathrm{M}$ $\mathrm{H}_{2} \mathrm{SO}_{4}$ at room temperature $\left(25^{\circ} \mathrm{C}\right)$.

For the determination of hydrogen peroxide concentrations on the novel electrode, cyclic voltammetry was used to determine the linear range, limit of detection, limit of quantification, selectivity and sensitivity. 


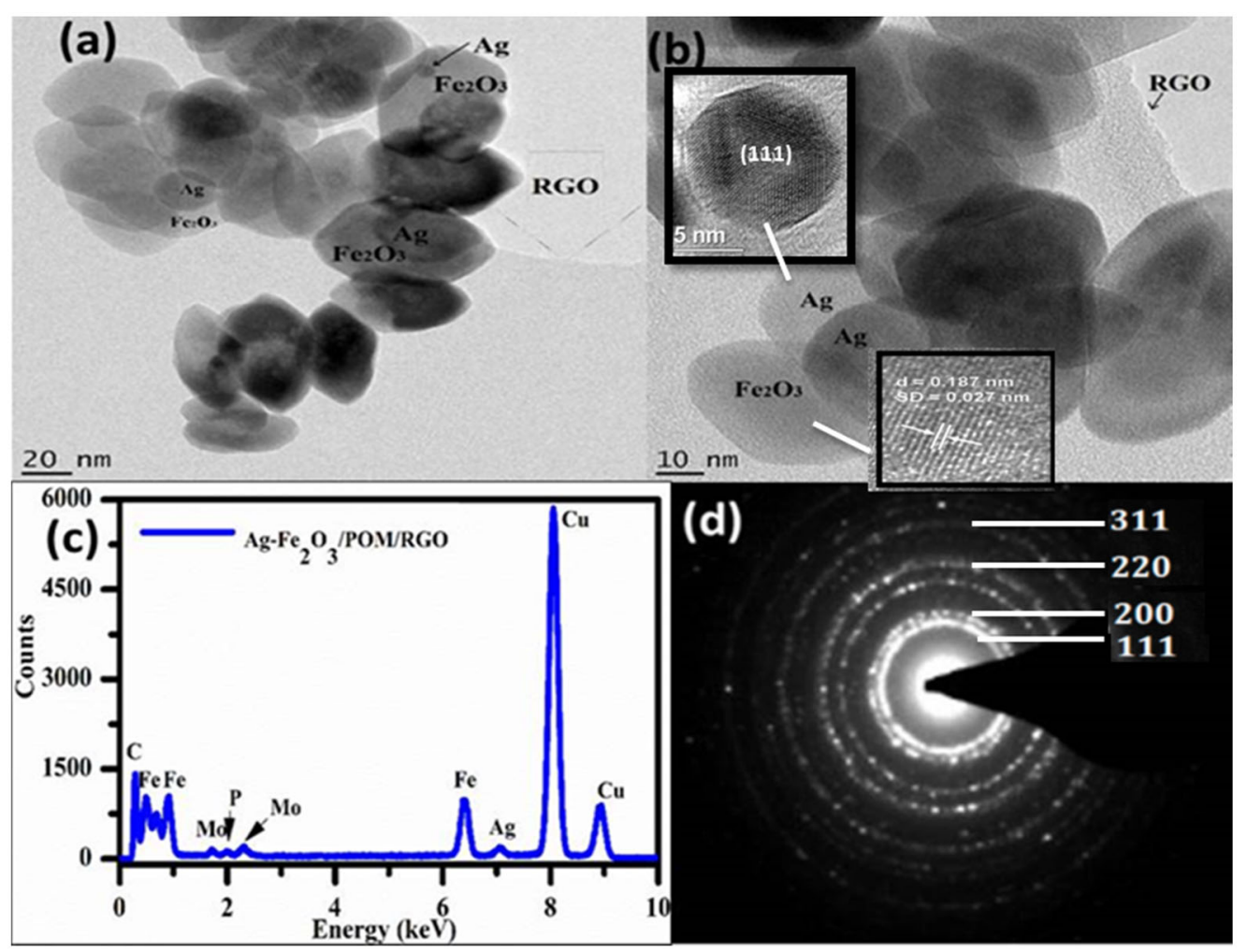

Figure 2. (a, b) TEM images of $\mathrm{Ag}-\mathrm{Fe}_{2} \mathrm{O}_{3} / \mathrm{POM} / \mathrm{RGO}$ at two magnifications with the corresponding (c) EDX and (d) selected area (electron) diffraction.

\section{Results and discussion}

\section{Physicochemical characterization}

The surface morphology of POM/RGO displays the RGO as highly beneficial in providing a high surface area on the glassy carbon electrode (Figure 1a). The well dispersed $\mathrm{H}_{3} \mathrm{Mo}_{12} \mathrm{O}_{40} \mathrm{P} \cdot \mathrm{xH}_{2} \mathrm{O}$ dark spots are the POM dispersed on the RGO sheet, indicating the strong synergy between $\mathrm{H}_{3} \mathrm{Mo}_{12} \mathrm{O}_{40} \mathrm{P} \cdot \mathrm{xH}_{2} \mathrm{O}$ and $\mathrm{RGO}$ substrate. The two-dimensional elemental map of the composite in the supplementary information confirms the presence of both RGO and $\mathrm{PMo}_{12}$ by the wide-ranging distribution and of $\mathrm{C}, \mathrm{Mo}, \mathrm{P}$, and O. Higher phosphorus composition corresponds to areas with a higher density of $\mathrm{PMo}_{12}$ clusters and more electrochemically active sites for electrolyte exposure, stimulating ion transfer which promotes the surface redox reactions.

The EDX spectrum of POM/RGO confirms the presence of $\mathrm{C}$, from RGO and the $\mathrm{P}$, $\mathrm{Mo}$ and $\mathrm{O}$ from the POM (Figure $1 \mathrm{~b}$ ). The inset further confirms the absence of nanoparticle aggregation upon the POM-functionalized RGO with a mean diameter of ca. $2.0 \mathrm{~nm}$ uniformly dispersed on the surface. The literature suggests that the POM particles interact with oxygen containing functional groups of activated carbon (Yang et al. 2016; Ross et al. 2019).

The surface morphology and size distribution of the novel $\mathrm{Ag}-\mathrm{Fe}_{2} \mathrm{O}_{3} / \mathrm{POM} / \mathrm{RGO}$ nanocomposite was further probed by transmission electron microscopy obtained at 


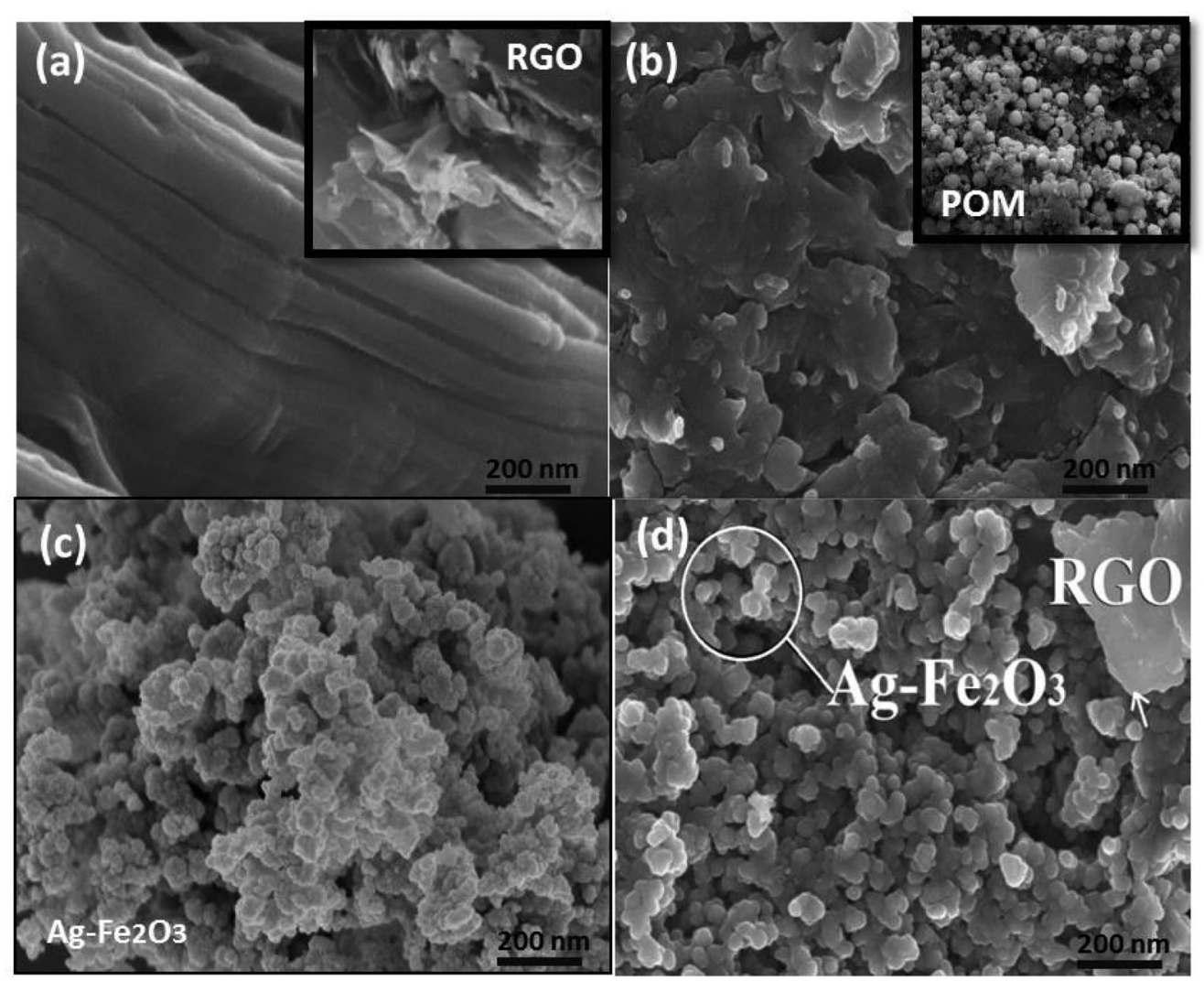

Figure 3. (a) SEM images of RGO (inset: 5,500x), (b) POM/RGO (inset: 5,500x), (c) $\mathrm{Ag}-\mathrm{Fe}_{2} \mathrm{O}_{3}$ nanoparticles and (d) $\mathrm{Ag}-\mathrm{Fe}_{2} \mathrm{O}_{3} / \mathrm{POM} / \mathrm{RGO}$ at a $200 \mathrm{~nm}$ scale view and 50,000x magnification.

different magnifications. The TEM images in Figure 2a,b show that the $\mathrm{Fe}_{2} \mathrm{O}_{3}$ and $\mathrm{Ag}$ nanoparticles are well distributed onto the RGO sheet. The Ag nanoparticles are spherical and highly dispersed upon the surface of $\mathrm{Fe}_{2} \mathrm{O}_{3}$. The irregular shaped $\mathrm{Fe}_{2} \mathrm{O}_{3}$ particles with diameters of $15.5 \pm 0.5 \mathrm{~nm}$ and the $4 \pm 1 \mathrm{~nm} \mathrm{Ag}$ nanoparticles are clearly visible.

These nanoparticles have less uniform dispersion with slight agglomeration possibly due to longer hydrothermal reaction time (Paul et al. 2016). The elemental composition and the structure of $\mathrm{Ag}-\mathrm{Fe}_{2} \mathrm{O}_{3} / \mathrm{POM} / \mathrm{RGO}$ were examined using $\mathrm{EDX}$ as shown in Figure 2c, with no impurities observed. The selected area (electron) diffraction (SAED) patterns further validate the high crystallinity of the $\mathrm{Ag}-\mathrm{Fe}_{2} \mathrm{O}_{3} / \mathrm{POM} / \mathrm{RGO}$ composite material.

Scanning electron microscopy. Figure 3 shows the surface morphology of the RGO nanosheets revealing a smooth, clearly discernible flaky surface with the randomly deposited POM units visible on the surface of the reduced graphene oxide. The $\mathrm{Ag}-\mathrm{Fe}_{2} \mathrm{O}_{3}$ nanoparticles are shown to be cubic and highly uniform in size. The Ag- $\mathrm{Fe}_{2} \mathrm{O}_{3} / \mathrm{POM} / \mathrm{RGO}$ nanocomposite appears to be composed of clustered particles approximately $100 \mathrm{~nm}$ in size, covering the whole area analyzed. 

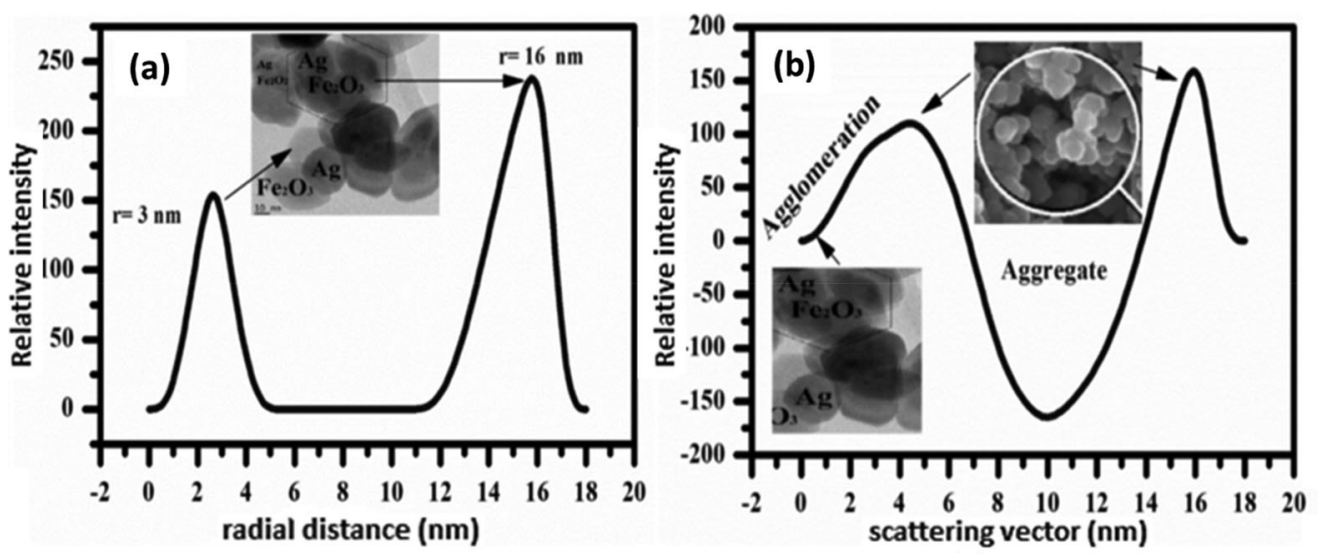

Figure 4. (a) SAXS analysis size distribution in terms of volume and (b) the corresponding intensity of the $\mathrm{Ag}-\mathrm{Fe}_{2} \mathrm{O}_{3}$ nanoparticles. The scattering pattern is analyzed below $10^{\circ} 2 \theta$, and domains in a size range for diameters from 1 to $100 \mathrm{~nm}$.

\section{SAXS analysis and comparison with the SEM and TEM images}

Small angle x-ray scattering (SAXS) was used to study the nanoparticle shape, sizes and distribution. Figure 4a shows the size distribution of the $\mathrm{Ag}-\mathrm{Fe}_{2} \mathrm{O}_{3}$ nanoparticles in terms of volume corresponding to the SEM image of $\mathrm{Ag}-\mathrm{Fe}_{2} \mathrm{O}_{3} / \mathrm{POM} / \mathrm{RGO}$ at $10 \mathrm{~nm}$ as shown in the inset. A downward trajectory toward the negative region is observed with a second peak appearing at approximately $16 \mathrm{~nm}$. These measurements are good agreement with the TEM results which are indicative of inhomogeneous nanoparticle accumulation.

Figure $4 \mathrm{~b}$ shows the size distribution in terms of the intensity (Schnablegger and Singh 2013; Sass, Mouele, and Ross 2019) along with TEM images of the $\mathrm{Ag}-\mathrm{Fe}_{2} \mathrm{O}_{3} /$ $\mathrm{POM} / \mathrm{RGO}$ composite in the inset. The $16 \mathrm{~nm}$ sized nanoparticle is more intense compared to the $3 \mathrm{~nm}$ sized particles. The calculated size distribution of the $\mathrm{Fe}_{2} \mathrm{O}_{3}$ nanoparticles by the Image J software is in good agreement with the SAXS measurements. The SAXS curve at high q values is indicative of a wider relative size distribution (Pabisch et al. 2012; Gong et al. 2015).

\section{Chemical characterization}

\section{FTIR analysis}

FT-IR spectroscopy was used to probe the formation of the POM/RGO hybrid material based upon the structural and conformational changes which serve as a wonderful complement to the SAXS analysis. Figure 5a,b shows the GO and RGO spectra, respectively. The spectrum of GO has a broad band at $3172 \mathrm{~cm}^{-1}$, which is due to a strong stretching mode of $\mathrm{OH}$ group, an absorption peak at $1630 \mathrm{~cm}^{-1}$ due to $\mathrm{C}=\mathrm{C}$ stretching mode and peaks at $1120 \mathrm{~cm}^{-1}$, which correspond to the stretching modes of $\mathrm{C}-\mathrm{OH}$.

Conversely, for RGO, the absorption peak in the $3172 \mathrm{~cm}^{-1}$ region disappeared, which reveals the absence of the $\mathrm{OH}$ group after the reduction. Concomitantly, the absorption peak at $1047 \mathrm{~cm}^{-1}$ is attributed to $\mathrm{C}-\mathrm{OH}$ which effectively exfoliated some of the partial functional groups in GO (Goertz, Dingenouts, and Nirschl 2009). 

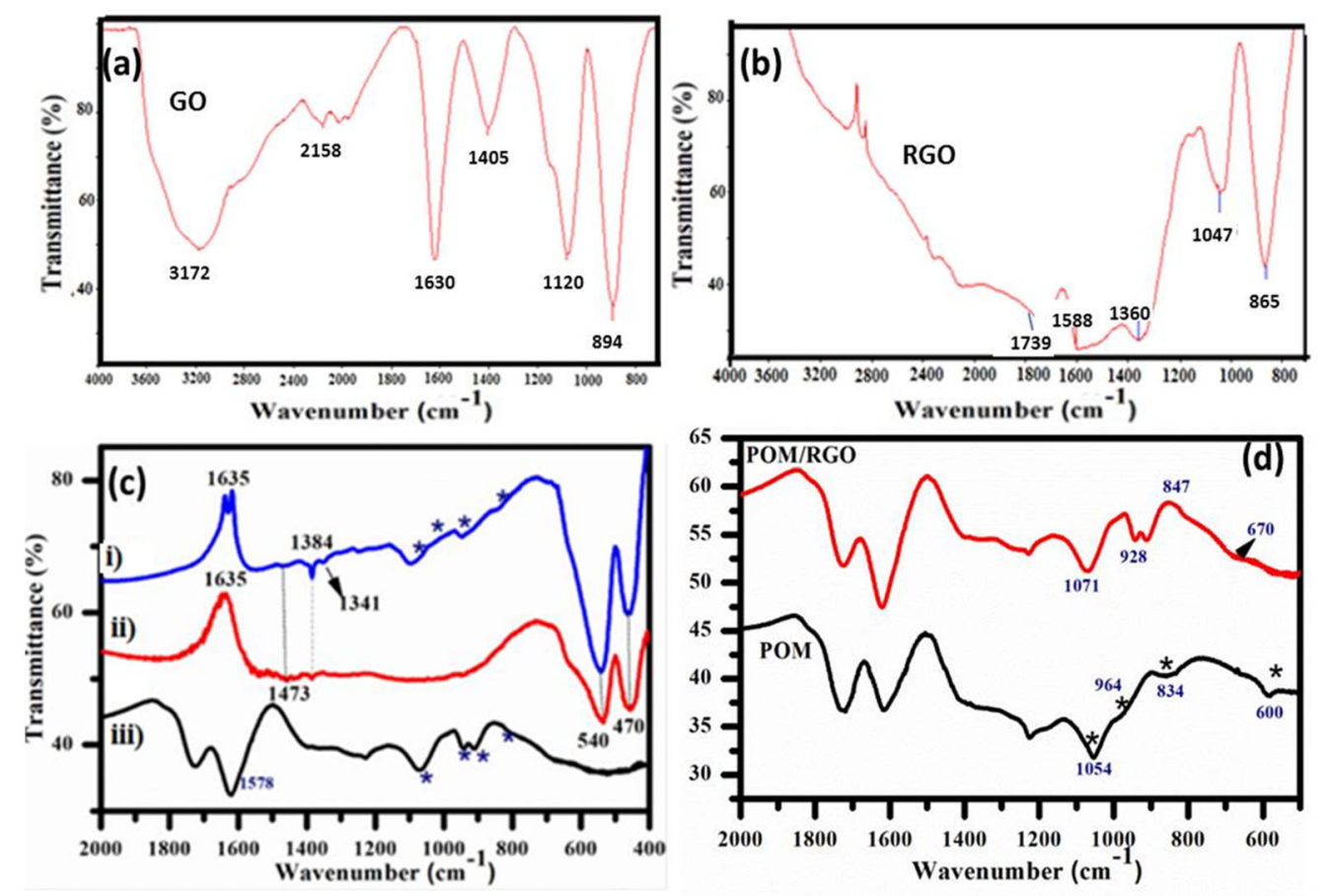

Figure 5. (a) FTIR spectra of exfoliated GO; (b) RGO; (c) (i) POM, (ii) POM/RGO and (iii) $\mathrm{Ag}-\mathrm{Fe}_{2} \mathrm{O}_{3} /$ $\mathrm{POM} / \mathrm{RGO}$ nanocomposite; and (d) POM and POM/RGO from 2000 to $500 \mathrm{~cm}^{-1}$. The pure POM (*) exhibited characteristic peaks at $1054 \mathrm{~cm}^{-1}, 964 \mathrm{~cm}^{-1}, 834 \mathrm{~cm}^{-1}$ and $600 \mathrm{~cm}^{-1}$.

Figure $5 \mathrm{c}$, d shows the structural changes related to POM/RGO, $\mathrm{Ag}-\mathrm{Fe}_{2} \mathrm{O}_{3}$ and novel Ag- $\mathrm{Fe}_{2} \mathrm{O}_{3} / \mathrm{POM} / \mathrm{RGO}$ composites. The absorption peaks at 1071, 928, 847 and $670 \mathrm{~cm}^{-1}$ in the POM/RGO spectrum are also present $\left(1098,941,840\right.$ and $\left.709 \mathrm{~cm}^{-1}\right)$ but with slight shifting. These are due to the oxygen functional groups in POM/RGO interacting with the $\mathrm{Fe}_{2} \mathrm{O}_{3}$ nanoparticles (Xiao et al. 2015). The $\mathrm{Ag}-\mathrm{Fe}_{2} \mathrm{O}_{3}$ strong absorption bands at $540 \mathrm{~cm}^{-1}$ and $470 \mathrm{~cm}^{-1}$ due to the Fe-O bond may be observed (Paul et al. 2015; Ross et al. 2016). These absorption bands are present in the spectrum of $\mathrm{Ag}-\mathrm{Fe}_{2} \mathrm{O}_{3} / \mathrm{POM} /$ RGO with higher intensity.

In addition, the peak at $540 \mathrm{~cm}^{-1}$ is due to the lattice absorption of iron oxide, indicating the strong interactions of the nanoparticles with the ester oxygens. The weaker absorption bands at $1473 \mathrm{~cm}^{-1}, 1384 \mathrm{~cm}^{-1}$, and $1635 \mathrm{~cm}^{-1}$ are primarily responsible for the reduction of Ag. These peaks are also present in the novel nanocomposite spectrum, with the absorbance band at $1384 \mathrm{~cm}^{-1}$ associated with the stretching vibration of functional groups such as $-\mathrm{C}-\mathrm{O}-\mathrm{C}-,-\mathrm{C}-\mathrm{O}-,-\mathrm{C}=\mathrm{C}, \mathrm{C}=\mathrm{O}$ (Hu et al. 2018).

\section{$X$-ray diffraction}

To further corroborate these findings, the chemical components and the crystalline structure of the novel Ag- $\mathrm{Fe}_{2} \mathrm{O}_{3} / \mathrm{POM} / \mathrm{RGO}$ nanocomposite were characterized by XRD. Figure 6 shows no distinct diffraction peaks of POM in the XRD spectra of POM/RGO, which further suggests that POM particles are highly dispersed on the surface of the RGO in the composite (Zhang and Zheng 2017; Seham et al. 2018). The $\mathrm{Ag}-\mathrm{Fe}_{2} \mathrm{O}_{3} /$ 


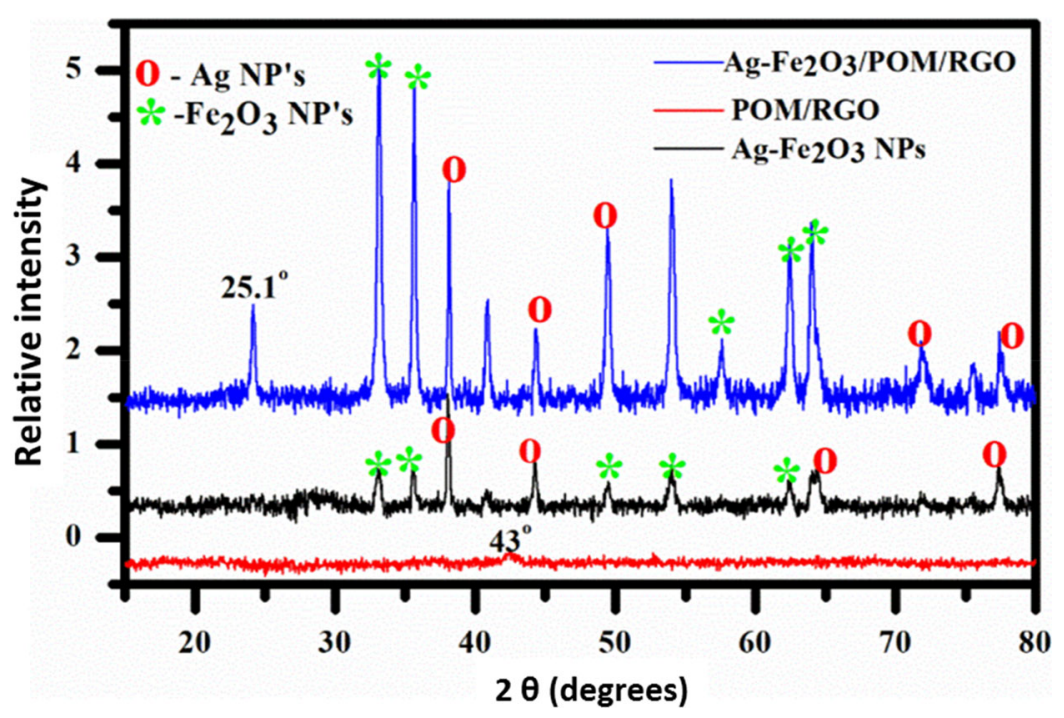

Figure 6. XRD spectrum of $\mathrm{POM} / \mathrm{RGO}, \mathrm{Ag}-\mathrm{Fe}_{2} \mathrm{O}_{3}$ nanoparticles and $\mathrm{Ag}-\mathrm{Fe}_{2} \mathrm{O}_{3} / \mathrm{POM} / \mathrm{RGO}$ nanocomposites.

$\mathrm{POM} / \mathrm{RGO}$ has peaks at $30.3^{\circ}, 35.6^{\circ}, 58.7^{\circ}, 62.9^{\circ}$ and $53.7^{\circ}$ which are assigned to diffraction from the (220), (311), (400), (422) and (533) planes of rhombohedral crystalline lattice $\mathrm{Fe}_{2} \mathrm{O}_{3}$ phase (JCPDS card number 33-0664).

The diffraction peaks at $38.1^{\circ}, 44.4^{\circ}, 48.9^{\circ}, 77^{\circ}$ and $79.4^{\circ}$ are well indexed to the (111), (200), (220), (311) and (222) planes of Ag cubic structure (JCPDS card number 04-0783). Additionally, the intensities of the diffraction peaks are increased in the Ag$\mathrm{Fe}_{2} \mathrm{O}_{3} / \mathrm{POM} / \mathrm{RGO}$ nanocomposite and the diffraction peaks are slightly shifted which may be due to the interaction between oxygen functional groups of POM/RGO and $\mathrm{Fe}_{2} \mathrm{O}_{3}$ (Kumar, Chandana, et al.). The x-ray diffraction measurements demonstrate that the $\mathrm{Ag}-\mathrm{Fe}_{2} \mathrm{O}_{3} / \mathrm{POM} / \mathrm{RGO}$ nanocomposite was successfully synthesized.

\section{Raman spectroscopic analysis}

The Raman spectra in Figure 7 of the nanocomposites of $\mathrm{Ag}-\mathrm{Fe}_{2} \mathrm{O}_{3} / \mathrm{POM} / \mathrm{RGO}$ reveals that the $\mathrm{I}_{\mathrm{D}} / \mathrm{I}_{\mathrm{G}}$ band of the $\mathrm{Ag}-\mathrm{Fe}_{2} \mathrm{O}_{3} / \mathrm{POM} / \mathrm{RGO}$ equal to 2.488 is higher compared to that of POM/RGO equal to 1.27, indicating the presence of $\mathrm{sp}^{3}$ defects with the $\mathrm{sp}^{2}$ carbon network after the hydrothermal treatment (Lui et al. 2015). Concomitantly, the D and $\mathrm{G}$ bands of POM/RGO are attributed to the strong interactions between RGO and POM in the nanocomposite (Chen et al. 2013). The sharp peak around $500 \mathrm{~cm}^{-1}$ for $\mathrm{POM} / \mathrm{RGO}$ may be assigned to the symmetric $\nu_{\mathrm{s}}(\mathrm{Mo}=\mathrm{O})$ stretching vibration of the peroxide group; confirming the nanocomposite formation ( $\mathrm{Lu}$ and Xie 2017).

From the $\mathrm{Ag}-\mathrm{Fe}_{2} \mathrm{O}_{3}$ nanoparticle spectrum, the characteristic $\mathrm{Fe}-\mathrm{O}$ bands of $\mathrm{Fe}_{2} \mathrm{O}_{3}$ are observed, which are centered at $402 \mathrm{~cm}^{-1}$ and $408 \mathrm{~cm}^{-1}$. These peaks are also observed in the spectrum of $\mathrm{Ag}-\mathrm{Fe}_{2} \mathrm{O}_{3} / \mathrm{POM} / \mathrm{RGO}$ but with a slight shift to $403 \mathrm{~cm}^{-1}$ and $483.70 \mathrm{~cm}^{-1}$, which confirm the formation of $\mathrm{Fe}_{2} \mathrm{O}_{3}$ nanoparticles in the novel composite (Velicky et al. 2014; Lou et al. 2016). The $\mathrm{Ag}-\mathrm{Fe}_{2} \mathrm{O}_{3} / \mathrm{POM} / \mathrm{RGO}$ spectrum also displayed a vibration band at $281 \mathrm{~cm}^{-1}$ that may be assigned to a $\mathrm{Ag}-\mathrm{O}$ mode and a 


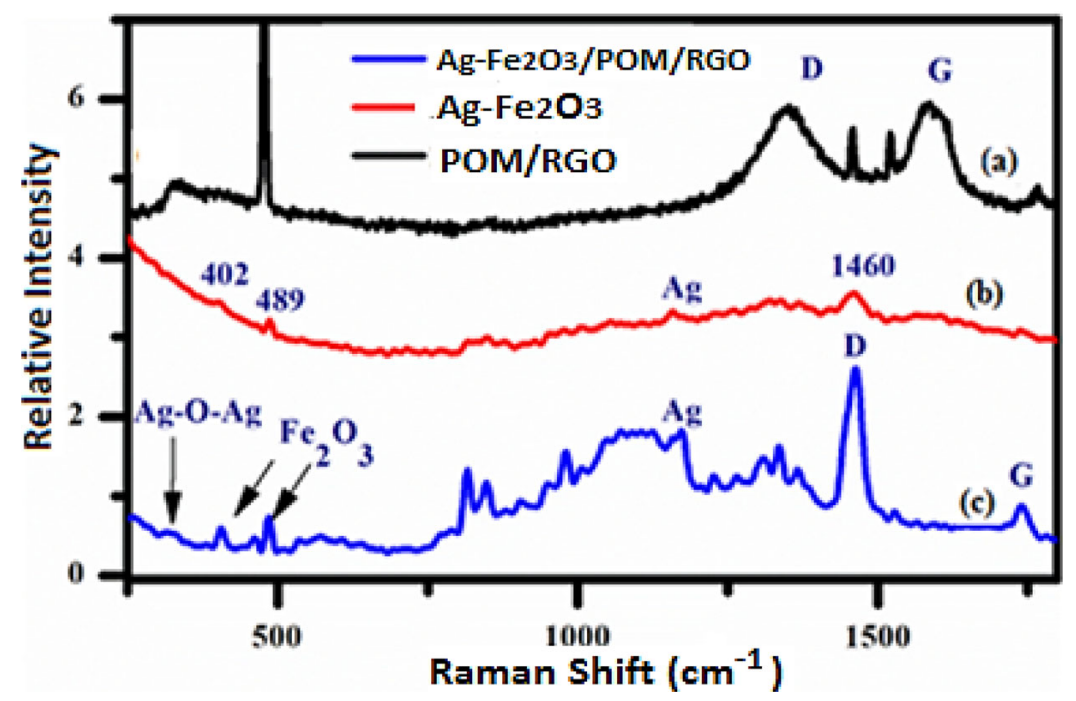

Figure 7. (a) Raman spectra of POM/RGO, (b) $\mathrm{Ag}-\mathrm{Fe}_{2} \mathrm{O}_{3}$ nanoparticles and (c) $\mathrm{Ag}-\mathrm{Fe}_{2} \mathrm{O}_{3} / \mathrm{POM} / \mathrm{RGO}$ at excitation wavelengths of $533 \mathrm{~nm}, 632.8 \mathrm{~nm}$ and $632.8 \mathrm{~nm}$, respectively.

vibration band at $1117 \mathrm{~cm}^{-1}$ for the $\mathrm{Ag}$ mode. These results confirm the successful hydrothermal synthesis of the $\mathrm{Ag}-\mathrm{Fe}_{2} \mathrm{O}_{3} / \mathrm{POM} / \mathrm{RGO}$ composite.

\section{Electrochemical analysis}

\section{Cyclic voltammetry (CV)}

To conduct cyclic voltammetric measurements, $3 \mu \mathrm{L}$ of POM/RGO suspension dispersed in $1 \mathrm{~mL}$ ethanol solution were drop coated onto a GCE and dried at room temperature to form the POM/RGO/GCE. Figure 8a shows the cyclic voltammogram of the untreated GCE and POM modified GCE. Across the potential range from +0.8 to $-0.2 \mathrm{~V}$, the untreated electrode shows no visible electrochemistry. However, the POM/ RGO modified GCE shows three reversible redox couples.

The POM/GCE and POM/RGO/GCE electrodes displayed comparable electrochemical performance. However, due to the high surface area and electronic conductivity of the RGO, enhanced electron-transfer kinetics is evident in the latter (Manivel and Anandan 2011). Therefore, the results demonstrate that the interaction between the POM and the RGO stabilized the molecular anions and prevented them from leaching (Wang et al. 2014).

Figure $8 \mathrm{~b}$ shows a cyclic voltammogram of the POM/RGO modified GCE in $0.5 \mathrm{M}$ $\mathrm{H}_{2} \mathrm{SO}_{4}$. At different scan rates, three reversible redox peaks and one weak irreversible peak at $E_{1 / 2} 0.35 \mathrm{~V}, 0.21 \mathrm{~V}$ and $-0.1 \mathrm{~V}$ were observed with a peak potential separation of approximately $60 \mathrm{mV}$. Redox peaks one, two and three corresponds to the reduction and oxidation via two-, four-, and six-electron processes, respectively, which are described by the following equations (Ivanova and Zamborini 2010):

$$
\begin{gathered}
\mathrm{PMo}_{12} \mathrm{O}_{40}^{3-}+2 e^{-}+2 \mathrm{H}^{+} \rightarrow \mathrm{H}_{2} \mathrm{PMo}_{12} \mathrm{O}_{40}^{3-} \\
\mathrm{H}_{2} \mathrm{PMo}_{12} \mathrm{O}_{40}^{3-}+2 e^{-}+2 \mathrm{H}^{+} \rightarrow \mathrm{H}_{4} \mathrm{PMo}_{12} \mathrm{O}_{40}^{3-}
\end{gathered}
$$



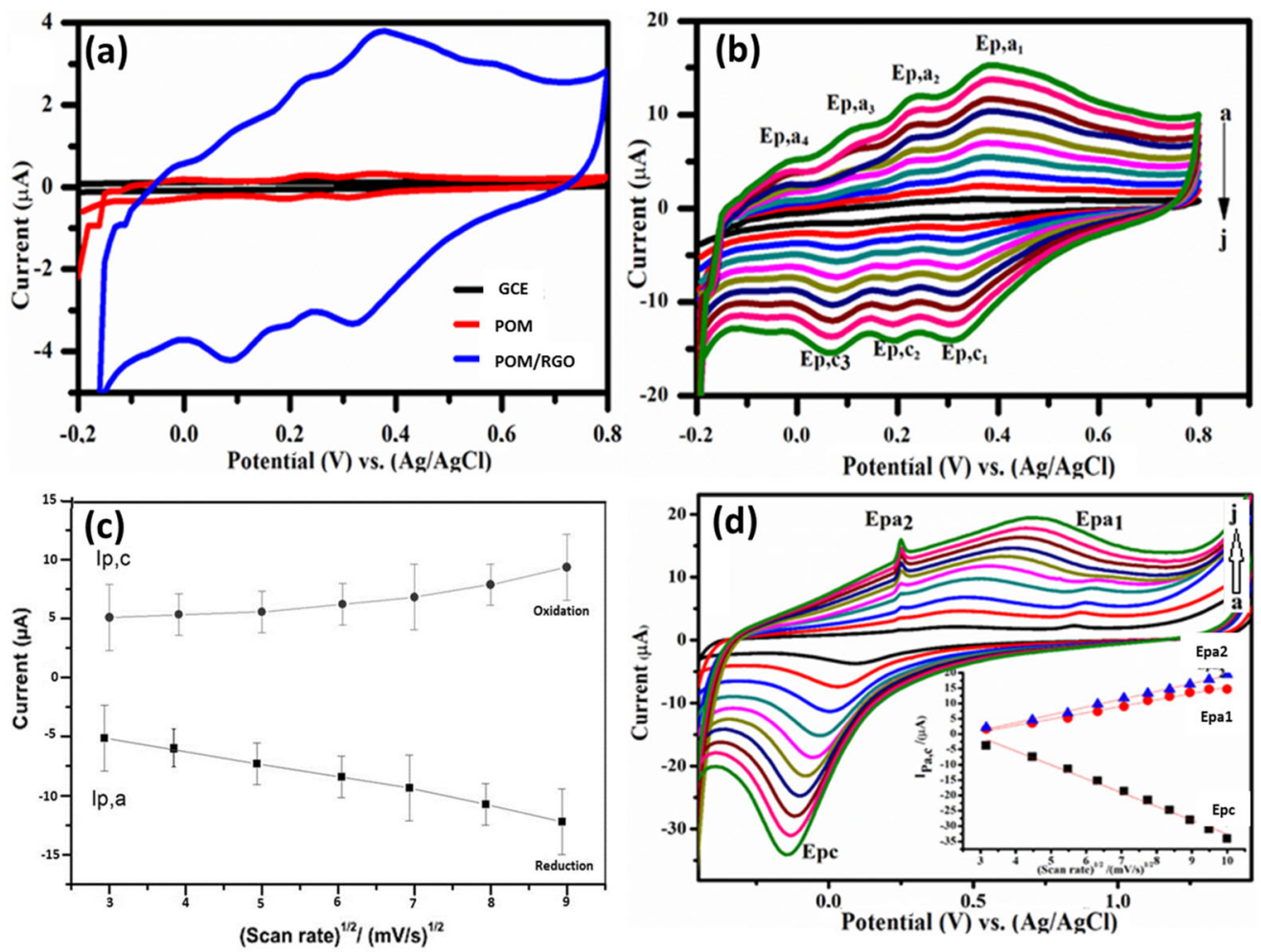

Figure 8. (a) Cyclic voltammograms of POM, GCE and POM/RGO cycled at $30 \mathrm{mV} \mathrm{s}^{-1}$. (b) POM/RGO/ GCE as a function of scan rate. (c) Peak current plot for the determination of the diffusion coefficient with $\mathrm{R}^{2}$ equal to 0.9598 for the cathodic and 0.9676 for anodic plots, respectively. (d) Scan rate characterization for $\mathrm{Ag}-\mathrm{Fe}_{2} \mathrm{O}_{3} / \mathrm{POM} / \mathrm{RGO} / \mathrm{GCE}$ from 10 to $100 \mathrm{mV} \mathrm{s}^{-1}$ in $0.5 \mathrm{M} \mathrm{H}_{2} \mathrm{SO}_{4}$. The inset shows the Randles-Sevcik plot for oxidation peak potentials Epa1, Epa2 and reduction peak potential, Epc.

$$
\mathrm{H}_{4} \mathrm{PMo}_{12} \mathrm{O}_{40}^{3-}+2 e^{-}+2 \mathrm{H}^{+} \rightarrow \mathrm{H}_{6} \mathrm{PMo}_{12} \mathrm{O}_{40}^{3-}
$$

The peak currents are proportional to the scan rate as shown in Figure 8c, with a linear relationship observed between the anodic and cathodic peak currents as a function of (scan rate) ${ }^{1 / 2}$; supported by $\mathrm{R}^{2}$ values of 0.9598 for the cathodic and 0.9676 for the anodic reaction for redox couple 2. These results demonstrate that the reaction of POM on the surface of RGO was a diffusion-controlled process.

Figure $8 \mathrm{~d}$ shows the electrochemistry of $\mathrm{Ag}-\mathrm{Fe}_{2} \mathrm{O}_{3} / \mathrm{POM} / \mathrm{RGO}$ drop coated onto a GCE. The modified electrode (Sensor) was cycled in the $0.5 \mathrm{M} \mathrm{H}_{2} \mathrm{SO}_{4}$ solution at scan rates from $10 \mathrm{mV} / \mathrm{s}$ to $100 \mathrm{mV} \mathrm{s}^{-1}$. The figure shows that as the scan rate is increased, there is an enhancement in the current. The cyclic voltammogram shows three redox peaks, two anodic peaks and one cathodic peak. The anodic peak potential is proportional to the square root of scan rate with the regression equation:

$$
I_{p 2}(\mu A)=2.5659\left(\frac{m V}{s}\right)^{\frac{1}{2}}-6.517
$$

with $\mathrm{R}^{2}$ equal to 0.988 . 


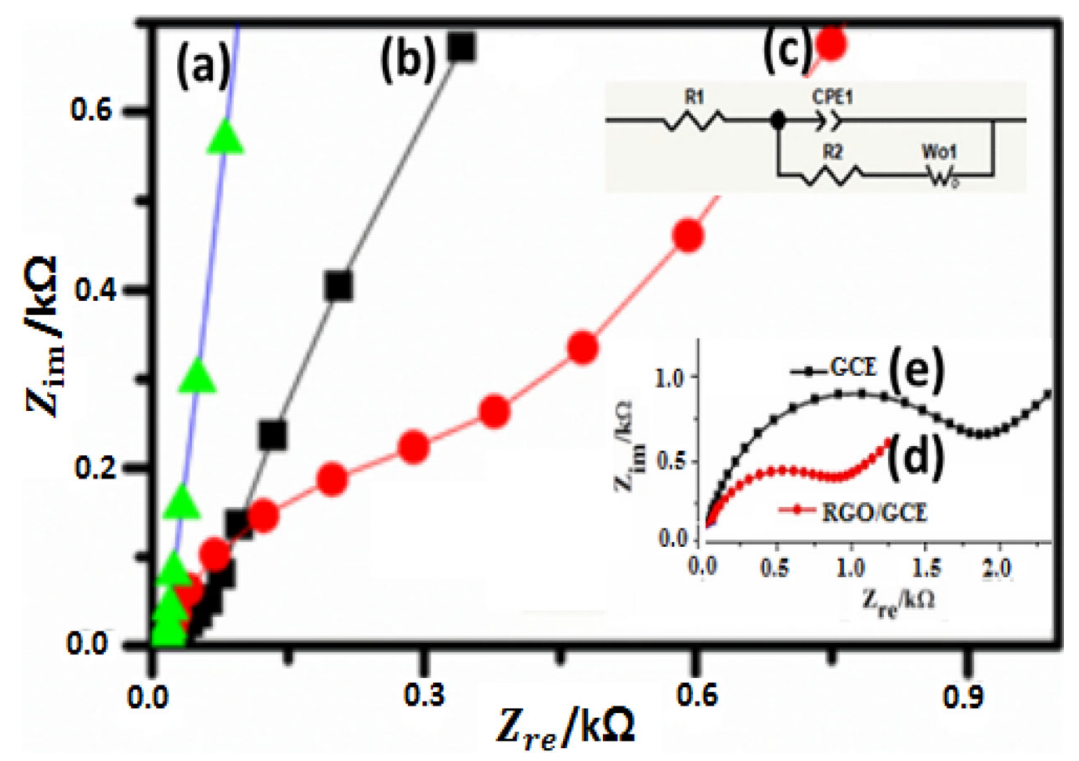

Figure 9. Nyquist plots: real impedance change $\left(Z_{\mathrm{re}}\right)$ as a function of the imaginary impedance change $\left(\left|Z_{i m}\right|\right)$ of the (a) $\mathrm{Ag}-\mathrm{Fe}_{2} \mathrm{O}_{3}$ nanoparticles, (b) POM/RGO, (c) $\mathrm{Ag}-\mathrm{Fe}_{2} \mathrm{O}_{3} / \mathrm{POM} / \mathrm{RGO}$, (d) $\mathrm{RGO} / \mathrm{GCE}$ and (e) GCE in $0.5 \mathrm{M} \mathrm{H}_{2} \mathrm{SO}_{4}$. The inset shows the Randles circuit consisting of the solution resistance $\left(R_{1}\right)$, charge transfer resistance $\left(R_{2}\right)$, constant phase element (CPE1) and the Warburg element (Wo1).

Well-defined redox peaks $\mathrm{E}_{\mathrm{pa} 1}$ and $\mathrm{E}_{\mathrm{pc}}$ were observed at $0.57 \mathrm{~V}$ and $-0.08 \mathrm{~V}$ which corresponds to the $\mathrm{Fe}^{3+} / \mathrm{Fe}^{2+}$ couple (Zhang et al. 2016; Liu, Weng, et al. 2017). The obvious peaks in the $\mathrm{CV}$ of the composite confirm that the reaction arising from $\mathrm{Fe}_{2} \mathrm{O}_{3}$ nanoparticles provides a major contribution on the sensor's performance. The highly dispersed $\mathrm{Ag}-\mathrm{Fe}_{2} \mathrm{O}_{3}$ in the composites is beneficial for electrocatalytic reduction of $\mathrm{H}_{2} \mathrm{O}_{2}$ because more active sites are available. The diffusion coefficient of the electron through the composite sensor material was determined using the Randle-Sevcik equation:

$$
I_{p}=2.69 \times 10^{5} n^{3 / 2} A C D^{1 / 2} v^{1 / 2}
$$

where $I_{p}$ is the maximum current, $\mathrm{n}$ is the number of electrons transferred in the redox event, $\mathrm{A}$ is the area of the glassy carbon electrode $\left(0.071 \mathrm{~cm}^{2}\right), \mathrm{C}$ is the concentration $\left(\mathrm{mol} / \mathrm{cm}^{3}\right), \mathrm{D}$ is the diffusion coefficient $\left(\mathrm{cm}^{2} / \mathrm{s}\right)$, and $\mathrm{v}$ is the scan rate $(\mathrm{V} / \mathrm{s})$. The diffusion coefficient was determined to be $2.35 \times 10^{-4} \mathrm{~cm}^{2} \mathrm{~s}^{-1}$. This value is consistent with literature reports (Peng et al. 2012; Sass, Mouele, and Ross 2019), indicating that the Ag- $\mathrm{Fe}_{2} \mathrm{O}_{3}$ nanoparticles on the surface of the RGO sheets improved the electrocatalytic properties due to the large electro-active area as well as providing more pathways for electrolyte ion diffusion.

\section{Electrochemical impedance spectroscopy (EIS)}

Figure 9 shows the Nyquist plot of the (a) Ag- $\mathrm{Fe}_{2} \mathrm{O}_{3}$ nanoparticles, (b) POM/RGO and (c) $\mathrm{Ag}-\mathrm{Fe}_{2} \mathrm{O}_{3} / \mathrm{POM} / \mathrm{RGO}$ in $0.5 \mathrm{M} \mathrm{H}_{2} \mathrm{SO}_{4}$ solution. To support the influence of the POM, the Nyquist plots of (d) RGO modified GCE and (e) bare GCE are also shown with their corresponding $\mathrm{R}_{\mathrm{ct}}$ values of 380.4 and $18.4 \Omega$, respectively. Upon electrode 


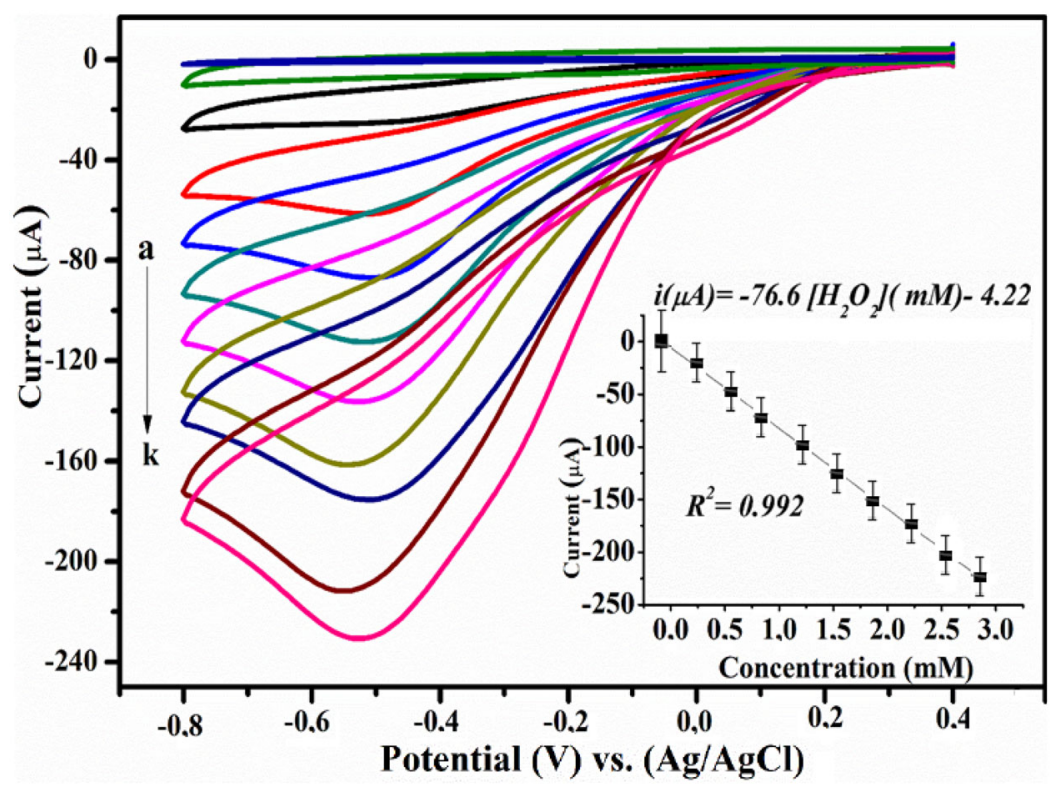

Figure 10. Electrochemical reduction of $\mathrm{H}_{2} \mathrm{O}_{2}$ by $\mathrm{Ag}-\mathrm{Fe}_{2} \mathrm{O}_{3} / \mathrm{POM} / \mathrm{RGO} / \mathrm{GCE}$ in nitrogen at $\mathrm{pH}$ 7.4. The concentrations of $\mathrm{H}_{2} \mathrm{O}_{2}$ were (a) 0 , (b) 0.3, (c) 0.6, (d) 0.9, (e) 1.3, (f) 1.6, (g) 1.9, (h) 2.3, (i) 2.6, and (j) $2.9 \mathrm{mM}$ at a scan rate of $0.03 \mathrm{~V} \mathrm{~s}^{-1}$. The inset shows the calibration relationship for $\mathrm{H}_{2} \mathrm{O}_{2}$ at the $\mathrm{Ag}-\mathrm{Fe}_{2} \mathrm{O}_{3} / \mathrm{POM} / \mathrm{RGO} / \mathrm{GCE}$.

modification with the $\mathrm{Ag}-\mathrm{Fe}_{2} \mathrm{O}_{3}$ nanoparticles and POM, charge transfer resistance $\left(\mathrm{R}_{\mathrm{ct}}\right)$ values of $81 \Omega$ and $54 \Omega$ were obtained, respectively. These values reveal that the charge transfer resistance for $\mathrm{Ag}-\mathrm{Fe}_{2} \mathrm{O}_{3}$ and POM modified GCE is lower than for the unmodified GCE due to the improved electron transfer and enhanced electron shuttling between the reactant and electrode surface.

The synergy between the POM/RGO and the nanoparticles were further confirmed by the lowering of the electron-transfer resistance value to $7 \Omega$ following the addition of Ag- $\mathrm{Fe}_{2} \mathrm{O}_{3}$ nanoparticles upon the POM/RGO/GCE surface. These results are indicative of the excellent electrochemical behavior of the $\mathrm{Ag}-\mathrm{Fe}_{2} \mathrm{O}_{3}$ induced by the firmly anchored POM with optimum surface area. The experimental results were fitted to a standard Randles equivalent circuit (inset) which is composed of the solution resistance $\left(\mathrm{R}_{1}\right)$, charge transfer resistance $\left(R_{2}\right)$, constant phase element (CPE 1) and Wo1 for the Warburg element. This process models the influences of diffusion and concentration gradients at the film interface.

\section{Application of the $\mathrm{AgFe}_{2} \mathrm{O}_{3} / \mathrm{POM} / \mathrm{RGO}$ nanocomposite as a platform for the determination of $\mathrm{H}_{2} \mathrm{O}_{2}$}

\section{Voltammetric response}

Figure 10 shows the electrochemical reduction of $\mathrm{H}_{2} \mathrm{O}_{2}$ by the $\mathrm{Ag}-\mathrm{Fe}_{2} \mathrm{O}_{3} / \mathrm{POM} / \mathrm{RGO} /$ GCE sensor. The cyclic voltammogram of $\mathrm{Ag}-\mathrm{Fe}_{2} \mathrm{O}_{3} / \mathrm{POM} / \mathrm{RGO} / \mathrm{GCE}$ in nitrogen-saturated $0.1 \mathrm{M}$ phosphate buffer at $\mathrm{pH} 6.8$ at $30 \mathrm{mV} \mathrm{s}^{-1}$ exhibits the highest reduction 


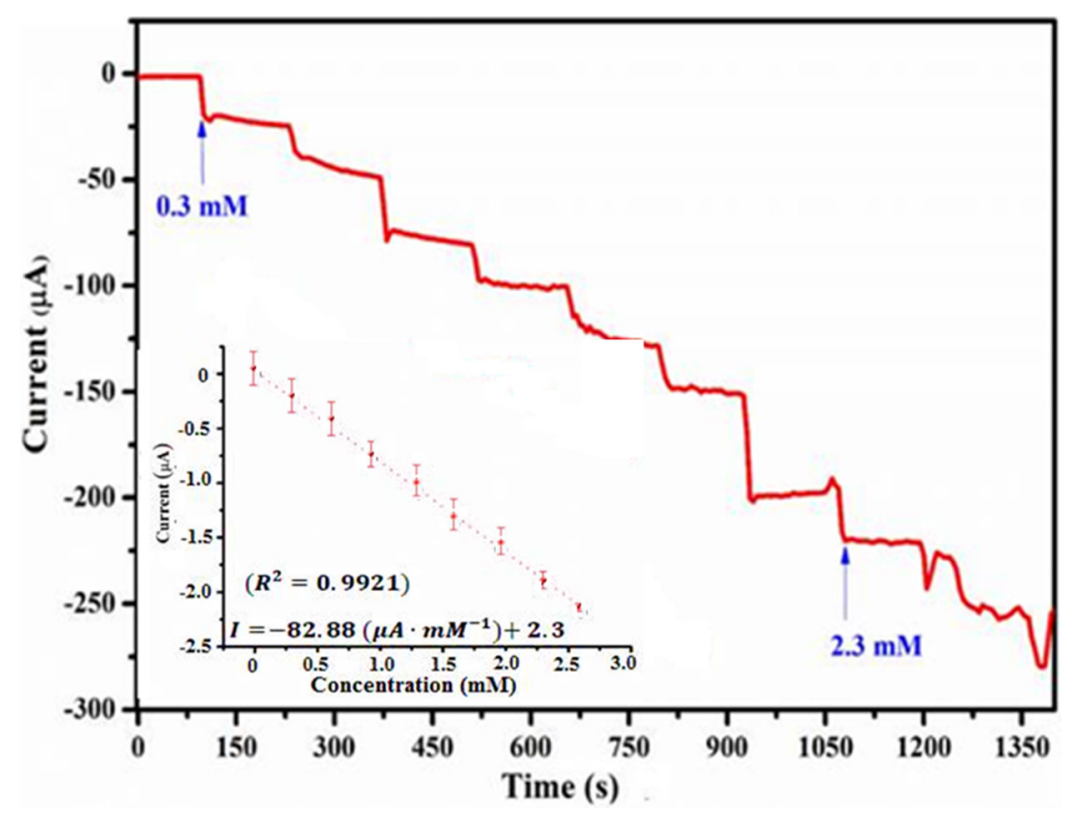

Figure 11. Current-time responses of $\mathrm{Ag}-\mathrm{Fe}_{2} \mathrm{O}_{3} / \mathrm{POM} / \mathrm{RGO}$ with the subsequent addition of $\mathrm{H}_{2} \mathrm{O}_{2}$ into $0.1 \mathrm{M}$ phosphate buffer solution at $\mathrm{pH} 6.8$ and $-0.5 \mathrm{~V}$. The inset shows the calibration response of the developed sensor.

activity toward hydrogen peroxide at $-0.55 \mathrm{~V}$ versus the saturated calomel electrode (SCE). The results showed that when $0,0.3,0.6,0.9,1.3,1.6,1.9,2.3,2.6$, and $2.9 \mathrm{mM}$ $\mathrm{H}_{2} \mathrm{O}_{2}$ were added, the reduction potential was shifted to more negative values indicating an irreversible reduction process with increased current responses (Qi and Zheng 2016). The cathodic peak current showed a linear relationship with the concentration $\left(\mathrm{R}^{2}\right.$ equal to 0.992 ) and the linear correlation was described by the following relationship (Bard and Faulkner 2001):

$$
I_{(\mu \mathrm{A})}=-76.6\left[\mathrm{H}_{2} \mathrm{O}_{2}\right](m M)-4.22
$$

The Ag- $\mathrm{Fe}_{2} \mathrm{O}_{3} / \mathrm{POM} / \mathrm{RGO} / \mathrm{GCE}$ sensor displayed excellent catalytic performance for the reduction of hydrogen peroxide. The optimum working potential for the $\mathrm{H}_{2} \mathrm{O}_{2}$ reduction upon the modified electrode was determined by measuring the current of the electrodes at working potentials between 0 and $-1.0 \mathrm{~V}$.

\section{Amperometric response of the $\mathrm{Ag}-\mathrm{Fe}_{2} \mathrm{O}_{3} / \mathrm{POM} / \mathrm{RGO}$ electrode for the determination of hydrogen peroxide}

Figure 11 shows the amperometric response of the $\mathrm{Ag}-\mathrm{Fe}_{2} \mathrm{O}_{3} / \mathrm{POM} / \mathrm{RGO}$ sensor at $-0.55 \mathrm{~V}$ versus the saturated calomel electrode as a result of the successive addition of $\mathrm{H}_{2} \mathrm{O}_{2}$ to a stirred $0.1 \mathrm{M}$ phosphate buffer solution at $\mathrm{pH}$ 6.8. The response time was less than $5 \mathrm{~s}$. The current increased linearly with an enhanced hydrogen peroxide concentration from 300 to $3000 \mu \mathrm{M}$. The reproducibility of the prepared electrode was elucidated from its current response using six separately prepared electrodes using the same preparation protocol. 
Table 1. Comparison of the performance of the $\mathrm{Ag}-\mathrm{Fe}_{2} \mathrm{O}_{3} / \mathrm{POM} / \mathrm{RGO}$ sensor with recently reported sensors for hydrogen peroxide detection.

\begin{tabular}{|c|c|c|c|c|}
\hline Electrode modification & $\begin{array}{c}\text { Sensitivity } \\
\left(\mu \mathrm{A} \mathrm{mM}^{-1} \mathrm{~cm}^{-2}\right)\end{array}$ & $\begin{array}{c}\text { Linear } \\
\text { range }(\mu \mathrm{M})\end{array}$ & $\begin{array}{l}\text { Detection } \\
\text { limit }(\mu \mathrm{M})\end{array}$ & Reference \\
\hline $\begin{array}{l}\text { Ag nanoparticles/polydopamine } \\
\text { /graphene nanocomposites }\end{array}$ & 140 & $0.005-997$ & 0.68 & $\begin{array}{l}\text { Zhi-Min Ma } \\
\text { et al. (2019) }\end{array}$ \\
\hline $\begin{array}{l}\text { Polyoxometalate/reduced graphene } \\
\text { oxide composite }\end{array}$ & 95.6 & $100-2 \times 104$ & 1.02 & Yang et al. (2016) \\
\hline $\begin{array}{l}\text { Silver nanoparticles/magnetic ferrous } \\
\text { ferric oxide matrix }\end{array}$ & 135 & $0.5-4 \times 103$ & 0.2 & Qi and Zheng (2016) \\
\hline $\begin{array}{l}\text { Silver-ferric oxide/phosphomolybdic } \\
\text { acid hydrate/reduced graphene } \\
\text { oxide composite }\end{array}$ & 271 & $0.3-3 \times 103$ & 0.2 & This work \\
\hline
\end{tabular}

The electrode was further evaluated in terms of hydrogen peroxide determination by the analysis of samples from a local river as shown in the supplementary information. Low relative standard deviation values ranging from 0.9 to $4.2 \%$ were obtained. The results demonstrate excellent sensitivity and repeatability for the $\mathrm{Ag}-\mathrm{Fe}_{2} \mathrm{O}_{3} / \mathrm{POM} /$ RGO electrode.

The sensor provided a linear response to hydrogen peroxide with a relative standard deviation equal to $1.8 \%$ for four replicates. The calibration relationship was described by:

$$
I=-82.88\left(\mu \mathrm{A} \cdot m M^{-1}\right)+2.3\left(R^{2}=0.9921\right)
$$

The limit of quantification (LOQ) and the limit of detection (LOD) for the $\mathrm{Ag}-\mathrm{Fe}_{2} \mathrm{O}_{3} /$ $\mathrm{POM} / \mathrm{RGO}$ electrode were determined by the following relationships:

$$
\begin{gathered}
L O D=\frac{3 S_{D}}{b} \\
L O Q=\frac{10 S_{D}}{b}
\end{gathered}
$$

where $b$ is the slope of the calibration curve and $S_{D}$ is the standard deviation of the blank solution. The limits of detection and quantification were determined to be $0.2 \mu \mathrm{M}$ and $0.66 \mu \mathrm{M}$, respectively. The comparison with literature reports shown in Table 1 indicates that the present sensor has better or comparable analytical figures of merit than most of the previously described devices for the determination of hydrogen peroxide.

Concomitantly, the influence of interferences upon the determination of hydrogen peroxide was characterized. Figure 12 shows the current-time response of the Ag$\mathrm{Fe}_{2} \mathrm{O}_{3} / \mathrm{POM} / \mathrm{RGO}$ electrode that was obtained by the consecutive introduction of $\mathrm{H}_{2} \mathrm{O}_{2}$ and common interfering species such as uric acid (UA), glucose and ethanol (Shaikh, Parida, and Böhm 2016; Yang et al. 2016) into 0.1 M phosphate buffer at pH 6.8.

When $300 \mu \mathrm{M}$ of $\mathrm{H}_{2} \mathrm{O}_{2}$ were added, the current response increased significantly. However, following the introduction of uric acid (UA), glucose and ethanol, the response current was unaffected. The introduction of additional concentrations of $\mathrm{H}_{2} \mathrm{O}_{2}$ significantly increased the response. The signals due to the potentially electroactive interfering species are negligible which indicates that $\mathrm{Ag}-\mathrm{Fe}_{2} \mathrm{O}_{3} / \mathrm{POM} / \mathrm{RGO}$ electrode 


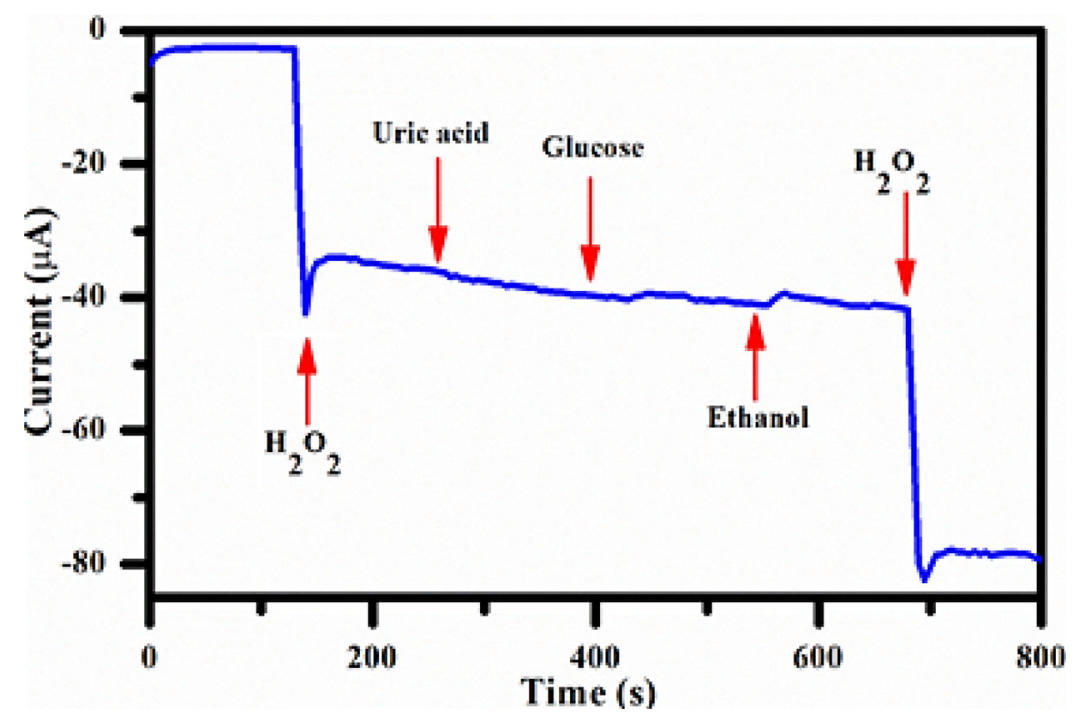

Figure 12. Amperometric response of $\mathrm{Ag}-\mathrm{Fe}_{2} \mathrm{O}_{3} / \mathrm{POM} / \mathrm{RGO}$ upon successive additions of $0.3 \mathrm{mM} \mathrm{H}_{2} \mathrm{O}_{2}$, uric acid, glucose, and ethanol into $0.1 \mathrm{M}$ phosphate buffer solution at $\mathrm{pH} 6.8$.

has superior selectivity for $\mathrm{H}_{2} \mathrm{O}_{2}$. The use of a negative working potential at $-0.55 \mathrm{~V}$ allowed the construction of an interference-free $\mathrm{Ag}-\mathrm{Fe}_{2} \mathrm{O}_{3} / \mathrm{POM} / \mathrm{RGO}$ electrode.

\section{Conclusion}

Phosphomolybdic acid $\left(\mathrm{H}_{3} \mathrm{PMo}_{12} \mathrm{O}_{40}\right)$ anchored onto reduced graphene oxide provided a catalytically stable environment for highly dispersed $\mathrm{Ag}-\mathrm{Fe}_{2} \mathrm{O}_{3}$ for the construction of a sensitive and selective non-enzymatic electrochemical sensor for hydrogen peroxide. The enhanced electrocatalytic ability is attributed to the larger surface area, enhanced conductivity and electron kinetics of the sensor components. The Ag- $\mathrm{Fe}_{2} \mathrm{O}_{3} / \mathrm{POM} / \mathrm{RGO}$ electrode exhibited good repeatability, reproducibility and selectivity for the determination of hydrogen peroxide. No significant current changes were observed for $1 \mathrm{mM}$ $\mathrm{H}_{2} \mathrm{O}_{2}$ in the presence of potential interferences. The low relative standard deviation values ranging from 0.9 to $4.2 \%$ in real samples with efficient signaling for $\mathrm{H}_{2} \mathrm{O}_{2}$ demonstrates promise for future use as a nonenzymatic sensor for the analysis of environmental water samples.

\section{ORCID}

Natasha Ross https://orcid.org/0000-0001-9238-319X

\section{Funding}

The authors would like to acknowledge the financial support of National Research Foundation (NRF, South Africa) and the Chemistry Department of the University of the Western Cape. 


\section{References}

Al-Hardan, N. H., M. A. Abdul Hamid, R. Shamsudin, E. M. Al-Khalqi, L. K. Keng, and N. M. Ahmed. 2018. Electrochemical hydrogen peroxide sensor based on macroporous silicon. Sensors 18 (3):716. doi:10.3390/s18030716.

Bai, G. R., K. Muthoosamy, F. N. Shipton, A. Pandikumar, P. Rameshkumar, N. M. Huang, and S. Manickam. 2016. The biogenic synthesis of a reduced graphene oxide-silver (RGO-Ag) nanocomposite and its dual applications as an antibacterial agent and cancer biomarker sensor. RSC Advances 6 (43):36576-87. doi:10.1039/C6RA02928K.

Bai, W., F. Nie, J. Zheng, and Q. Sheng. 2014. Novel silver nanoparticle-manganese oxyhydroxide-graphene oxide nanocomposite prepared by modified silver mirror reaction and its application for electrochemical sensing. ACS Applied Materials \& Interfaces 6 (8):5439-49. doi:10. 1021/am500641d.

Bader, H., V. Sturzenegger, and J. Hoigné. 1988. Photometric method for the determination of low concentrations of hydrogen peroxide by the peroxidase catalyzed oxidation of $\mathrm{N}, \mathrm{N}$ diethyl-p-phenylenediamine (DPD). Water Research 22 (9):1109-15. doi:10.1016/00431354(88)90005-X.

Bard, A. J., and L. R. Faulkner. 2001. Electrochemical Methods. Fundamentals and Applications. 2nd ed. New York: Wiley.

Chen, J., S. Liu, W. Feng, G. Zhang, and F. Yang. 2013. Fabrication phosphomolybdic acid-reduced graphene oxide nanocomposite by UV photo-reduction and its electrochemical properties. Physical Chemistry Chemical Physics 15 (15):5664. doi:10.1039/c3cp43638a.

Deng, Y., and Y. Zuo. 1999. Factors affecting the levels of hydrogen peroxide in rainwater. Atmospheric Environment 33 (9):1469-78. doi:10.1016/S1352-2310(98)00239-8.

Evanoff, D. D., and G. Chumanov. 2005. Synthesis and optical properties of silver nanoparticles and arrays. Chemphyschem. 6 (7):1221-31. doi:10.1002/cphc.200500113.

Farah, A. M., N. D. Shooto, F. T. Thema, J. S. Modise, and E. D. Dikio. 2012. Fabrication of Prussian blue/multi-walled carbon nanotubes modified glassy carbon electrode for electrochemical detection of hydrogen peroxide. International Journal of Electrochemical Science 7: 4302-13.

Goertz, V., N. Dingenouts, and H. Nirschl. 2009. Comparison of nanometric particle size distributions as determined by SAXS, TEM and analytical ultracentrifuge. Particle \& Particle Systems Characterization 26 (1-2):17-24. doi:10.1002/ppsc.200800002.

Gong, Y., D. Li, Q. Fu, and C. Pan. 2015. Influence of graphene microstructures on electrochemical performance for supercapacitors. Progress in Natural Science: Materials International 25 (5):379-85. doi:10.1016/j.pnsc.2015.10.004.

$\mathrm{Hu}, \mathrm{W}$., W. Zhang, Y. Wu, and W. Qu. 2018. Self-assembly and hydrothermal technique synthesized Fe2O3-RGO nanocomposite: The enhancement effect of electrochemical simultaneous detection of honokiol and magnolol. Journal of Electroceramics 40 (1):1-10. doi:10.1007/ s10832-017-0075-0.

Hsu, C. C., Y. R. Lo, Y. C. Lin, Y. C. Shi, and P. L. Li. 2015. A spectrometric method for hydrogen peroxide concentration measurement with a reusable and cost-efficient sensor. Sensors 15 (10):25716-29. doi:10.3390/s151025716.

Ivanova, O. S., and F. P. Zamborini. 2010. Size-dependent electrochemical oxidation of silver nanoparticles. Journal of the American Chemical Society 132 (1):70-2. doi:10.1021/ja908780g.

Keston, A. S., and R. Brandt. 1965. The fluorometric analysis of ultra-micro quantities of hydrogen peroxide. Analytical Biochemistry 11 (1):1-5. doi:10.1016/0003-2697(65)90034-5.

Kim, Y., and S. Shanmugam. 2013. Polyoxometalate-reduced graphene oxide hybrid catalyst: Synthesis, structure, and electrochemical properties. ACS Applied Materials \& Interfaces 5 (22): 12197-204. doi:10.1021/am4043245.

Kumar, V., R. K. Gupta, R. K. Gundampati, D. K. Singh, S. Mohan, S. H. Hasan and M. Malviya. 2018. Enhanced electron transfer mediated detection of hydrogen peroxide using a silver nanoparticle-reduced graphene oxide-polyaniline fabricated electrochemical sensor. RSC Advances 8 (2):619-31. doi:10.1039/C7RA11466D. 
Liu, H., L. Weng, and C. Yang. 2017. A review on nanomaterial-based electrochemical sensors for $\mathrm{H}_{2} \mathrm{O}_{2}, \mathrm{H}_{2} \mathrm{~S}$ and $\mathrm{NO}$ inside cells or released by cells. Microchimica Acta 184 (5):1267-83. doi:10.1007/s00604-017-2179-2.

Liu, R., S. Li, X. Yu, G. Zhang, S. Zhang, J. Yao, B. Keita, L. Nadjo, and L. Zhi. 2012. Facile synthesis of Au-nanoparticle/polyoxometalate/graphene tricomponentnanohybrids: An enzymefree electrochemical biosensor for hydrogen peroxide. Small 8 (9):1398-406. doi:10.1002/smll. 201102298.

Liu, S., J. Tian, L. Wang, and X. Sun. 2011. Microwave-assisted rapid synthesis of Ag nanoparticles/graphene nanosheet composites and their application for hydrogen peroxide detection. Journal of Nanoparticle Research 13 (10):4539-48. doi:10.1007/s11051-011-0410-3.

Loryuenyong, V., K. Totepvimarn, P. Eimburanapravat, W. Boonchompoo, and A. Buasri. 2013. Preparation and characterization of reduced graphene oxide sheets via water-based exfoliation and reduction methods. Advances in Materials Science and Engineering 2013:1-5. doi:10.1155/ 2013/923403.

Lou, X., C. Zhu, H. Pan, J. Ma, S. Zhu, D. Zhang, and X. Jiang. 2016. Cost-effective three dimensional graphene/Ag aerogel composite for high performance sensing. Electrochimica Acta 205: 70-6. doi:10.1016/j.electacta.2016.04.102.

Lu, L., and Y. Xie. 2017. Fabrication and supercapacitor behavior of phosphomolybdic acid/polyaniline/titanium nitride core-shell nanowire array. New Journal of Chemistry 41 (1):335-46. doi:10.1039/C6NJ02368A.

Ma, G., H. Xu, M. Wu, L. Wang, J. Wu, and F. Xu. 2019. A hybrid composed of MoS2, reduced graphene oxide and gold nanoparticles for voltammetric determination of hydroquinone, catechol, and resorcinol. Microchimica Acta 186 (11):689. doi:10.1007/s00604-019-3771-4.

Ma, G., M. Yang, G. Zhao, Y. Zhang, F. Xu, and L. Wang. 2016. Facile preparation of a threedimensional macroporous graphene wrapped cuprous oxide composite by one-step hydrothermal assembly for stable and sensitive hydrogen peroxide detection. Analytical Methods 8 (40): 7405-12. doi:10.1039/C6AY02244H.

Manivel, A., and S. Anandan. 2011. Silver nanoparticles embedded phosphomolybdate-polyaniline hybrid electrode for electrocatalytic reduction of $\mathrm{H}_{2} \mathrm{O}_{2}$. Journal of Solid State Electrochemistry 15 (1):153-60. doi:10.1007/s10008-010-1080-2.

Miao, J., H. Liu, W. Li, and X. Zhang. 2016. Mussel-inspired polydopamine-functionalized graphene as a conductive adhesion promoter and protective layer for silver nanowire transparent electrodes. Langmuir 32 (21):5365-72. doi:10.1021/acs.langmuir.6b00796.

Narasimharao, K., A. Al-Shehri, and S. Al-Thabaiti. 2015. Porous $\mathrm{Ag}-\mathrm{Fe}_{2} \mathrm{O}_{3}$ nanocomposite catalysts for the oxidation of carbon monoxide. Applied Catalysis A: General 505:431-40. doi:10. 1016/j.apcata.2015.05.017.

Pabisch, S., B. Feichtenschlager, G. Kickelbick, and H. Peterlik. 2012. Effect of interparticle interactions on size determination of zirconia and silica based systems - A comparison of SAXS, DLS, BET, XRD and TEM. Chemical Physics Letters 521:91-7. doi:10.1016/j.cplett.2011.11.049.

Pan, L., J. Tang, and Y. Chen. 2013. Synthesis of $\mathrm{Fe}_{3} \mathrm{O}_{4}, \mathrm{Fe} 2 \mathrm{O} 3, \mathrm{Ag} / \mathrm{Fe} 3 \mathrm{O} 4$ and $\mathrm{Ag} / \mathrm{Fe} 2 \mathrm{O} 3$ nanoparticles and their electrocatalytic properties. Science China Chemistry 56 (3):362-9. doi:10. 1007/s11426-012-4763-y.

Paul, B., D. D. Purkayastha, S. S. Dhar, S. Das, and S. Haldar. 2016. Facile one-pot strategy to prepare $\mathrm{Ag} / \mathrm{Fe} 2 \mathrm{O} 3$ decorated reduced graphene oxide nanocomposite and its catalytic application in chemoselective reduction of nitroarenes. Journal of Alloys and Compounds 681:316-23.

Paul, N., R. B. Hammond, T. N. Hunter, M. Edmondson, L. Maxwell, and S. Biggs. 2015. Synthesis of nuclear waste simulants by reaction precipitation: Formation of caesium phosphomolybdate, zirconium molybdate and morphology modification with citratomolybdate complex. Polyhedron 89:129-41. doi:10.1016/j.poly.2014.12.030.

Qi, C. C., and J. B. Zheng. 2016. Synthesis of $\mathrm{Fe}_{3} \mathrm{O}_{4}-\mathrm{Ag}$ nanocomposites and their application to enzymeless hydrogen peroxide detection. Chemistry Papers 70 (4):404-11. doi:10.1515/chempap-2015-0224.

Ross, N., N. W. Hlongwa, C. O. Ikpo, M. M. Ndipingwi, P. G. L. Baker, and E. I. Iwuoha. 2016. Iron-gold coated-LiMn2-XO4 nanowire high power cathode system probed by spectroscopic 
and microstructural analysis. Journal of Nano Research 44:10-20. doi:10.4028/www.scientific. net/JNanoR.44.10.

Ross, N., N. Nqakala, S. Willenberg, S. Sifuba, and E. Iwuoha. 2019. Electrochemical properties of polyoxometalate $\left(\mathrm{H} 3 \mathrm{PMo}_{12} \mathrm{O}_{40}\right)$-functionalized graphitic carbon nitride $\left(\mathrm{g}-\mathrm{C}_{3} \mathrm{~N}_{4}\right)$. Electrocatalysis 10 (4):392-8. doi:10.1007/s12678-019-00523-8.

Sadakane, M., and E. Steckhan. 1998. Electrochemical properties of polyoxometalates aselectrocatalysts. Chemical Reviews 98 (1):219-37. doi:10.1021/cr960403a.

Sass, D. T., E. S. M. Mouele, and N. Ross. 2019. Nano silver-iron-reduced graphene oxide modified titanium dioxide photocatalytic remediation system for organic dye. Environments 6:106. doi:10.3390/environments6090106.

Schnablegger, H., and Y. Singh. 2013. The SAXS guide: Getting acquainted with the principles. 3ee. Austria: Anton Paar GmbH.

Seham, A.-A., I. Andrey, R. N. Mozhchil, and N. Alim. 2018. Simple synthesis of graphene nanocomposites $\mathrm{MgO}-\mathrm{rGO}$ and $\mathrm{Fe}_{2} \mathrm{O}_{3}-\mathrm{rGO}$ for multifunctional applications. Applied Physics $A$ 124 (5):10. doi:10.1007/s00339-018-1748-5.

Shaikh, A., S. Parida, and S. Böhm. 2016. One step eco-friendly synthesis of Ag-reduced graphene oxide nanocomposite by phytoreduction for sensitive nitrite determination. RSC Advances 6 (102):100383-91. doi:10.1039/C6RA23655C.

Tarvin, M., B. McCord, K. Mount, K. Sherlach, and M. L. Miller. 2010. Optimization of two methods for the analysis of hydrogen peroxide: High performance liquid chromatography with fluorescence detection and high-performance liquid chromatography with electrochemical detection in direct current mode. Journal of Chromatography A 1217 (48):7564-72. doi:10. 1016/j.chroma.2010.10.022.

Teymourian, H., A. Salimi, and S. Khezrian. 2013. $\mathrm{Fe}_{3} \mathrm{O}_{4}$ magnetic nanoparticles/reduced graphene oxide nanosheets as a novel electrochemical and bioeletrochemical sensing platform. Biosensors and Bioelectronics 49:1-8. doi:10.1016/j.bios.2013.04.034.

Uchida, S., Y. Satoh, N. Yamashiro, and T. Satoh. 2004. Determination of hydrogen peroxide in water by chemiluminescence detection, (II) theoretical analysis of luminol chemiluminescence processes. Journal of Nuclear Science and Technology 41 (9):898-906. doi:10.1080/18811248. 2004.9715562.

Velicky, M., D. F. Bradley, A. J. Cooper, E. W. Hill, I. A. Kinloch, A. Mishchenko, K. S. Novoselov, H. V. Patten, P. S. Toth, A. T. Valota, et al. 2014. Electron transfer kinetics on mono- and multi-layer graphene. ACS Nano. 8 (10):10089-100. doi:10.1021/nn504298r.

Wang, L., M. Deng, G. Ding, S. Chen, and F. Xu. 2013. Manganese dioxide based ternary nanocomposite for catalytic reduction and nonenzymatic sensing of hydrogen peroxide. Electrochimica Acta 114:416-23. doi:10.1016/j.electacta.2013.10.074.

Wang, Z., Q. Han, J. Xia, L. Xia, S. Bi, G. Shi, F. Zhang, Y. Xia, Y. Li, and L. Xia. 2014. A novel phosphomolybdic acid-polypyrrole/graphene composite modified electrode for sensitive determination of folic acid. Journal of Electroanalytical Chemistry 726:107-11. doi:10.1016/j.jelechem.2014.05.013.

Xiao, L., M. Schroeder, S. Kluge, A. Balducci, U. Hagemann, C. Schulz, and H. Wiggers. 2015. Direct self-assembly of $\mathrm{Fe}_{2} \mathrm{O}_{3}$ /reduced graphene oxide nanocomposite for high-performance lithium-ion batteries. Journal of Materials Chemistry A 3 (21):11566-74. doi:10.1039/ C5TA02549D.

Xu, H., G. Ma, M. Wu, X. Peng, L. Wang, and F. Xu. 2019. One-pot preparation of three-dimensional macroporous phosphomolybdic acid-MoS2-reduced graphene oxide hybrid for electrochemical detection of nitrite. International Journal of Electrochemical Science 14:7258-69. doi: $10.20964 / 2019.08 .81$.

Xu, W. P., L. C. Zhang, J. P. Li, Y. Lu, H. H. Li, Y. N. Ma, W. D. Wang, and S.-H. Yu. 2011. Facile synthesis of silver@graphene oxide nanocomposites and their enhanced antibacterial properties. Journal of Materials Chemistry 21 (12):4593. doi:10.1039/c0jm03376f.

Yang, M. H., D. S. Kim, T. J. Lee, S. J. Lee, K. G. Lee, and B. G. Choi. 2016. Polyoxometalategrafted graphene nanohybrid for electrochemical detection of hydrogen peroxide and glucose. Journal of Colloid and Interface Science 468:51-6. doi:10.1016/j.jcis.2016.01.047. 
Yusoff, N., P. Rameshkumar, M. S. Mehmood, A. Pandikumar, H. W. Lee, and N. M. Huang. 2017. Ternary nanohybrid of reduced graphene oxide-nafion@silver nanoparticles for boosting the sensor performance in non-enzymatic amperometric detection of hydrogen peroxide. Biosensors and Bioelectronics 87:1020-8. doi:10.1016/j.bios.2016.09.045Zhang,.

Zhang, N., and J. Zheng. 2017. Synthesis of $\mathrm{Ag}-\mathrm{Fe}_{2} \mathrm{O}_{3}-\mathrm{RGO}$ nanocomposites for the electrocatalytic reduction of $\mathrm{H}_{2} \mathrm{O}_{2}$. Journal of Materials Science: Materials in Electronics 28 (15):11209-16. doi:10.1007/s10854-017-6909-3. 